\title{
David Oliver: Is abuse towards doctors in government roles unfair?
}

\author{
David Oliver consultant in geriatrics and internal medicine
}

Berkshire

The coronavirus pandemic has brought unaccustomed attention to doctors working in government departments and arm's length authorities. On social media there's been plenty of praise-but also some accusatory abuse.

The chief medical officer, currently Chris Whitty, has always been a public figure (the previous incumbent, Sally Davies, was fairly visible). But the past few weeks have also seen regular public appearances by the chief scientific adviser, Patrick Vallance; their deputies, Jenny Harries and Jonathan Van-Tam; Yvonne Doyle, medical director of Public Health England; Stephen Powis, NHS England medical director; and the chief nursing officer, Ruth May.

They've attracted criticism for occasional slips, such as Vallance mentioning "herd immunity" as a pandemic strategy. ${ }^{1}$ They've said things at odds with public and professional perception, such as Harries saying that the UK "has been an international exemplar in preparedness." And they've given some perceptions of inconsistency (changing Public Health England's advice on personal protective equipment, ${ }^{3}$ sometimes at odds with the World Health Organization) and back foot communications (May being initially reluctant to say how many NHS staff had died from coronavirus). ${ }^{4}$

Often, however, comments on social media have accused them of being political appointments, government shields or mouthpieces, or even dishonest. In the case of the women, some misogyny seemed to be at play.

\section{Apolitical appointments}

We won't know how competent or effective they've been, or how sound their scientific advice or medical leadership and advocacy has been, until this is all over. But I do want to defend them from allegations of bad faith, self-interest, or political motives.

These appointments are all apolitical. All have had long, distinguished careers. All would have been in post whatever the party of current government. Yes, the chief medical officer, chief scientific adviser, and their deputies are civil service appointees, and Public Health England is an executive agency of the Department of Health and Social Care (DHSC), and as such they're bound by the civil service code and contract. But the civil service supports and advises the party of government. ${ }^{5}$ Others work for NHS England and NHS Improvement-a non-departmental arm's length DHSC organisation that has at times been outspokenly critical of government policy or implemented workarounds to mitigate it.

For people in such roles, of course, openly and repeatedly challenging government policy would make their positions untenable, as they're part of collective responsibility and decision making. There will always be a choice of remaining influential inside the tent or resigning over a point of principle and speaking out. But if we want senior doctors and scientists inside government-which I do- they have a fine line to tread to remain useful.

Their job is to give expert advice to ministers and senior civil servants, to ensure that it's well evidenced and complete, to gain the widest range of relevant and current expertise, and to express that advice fearlessly within government and its agencies.

Ultimately, although the likes of Powis, May, and Doyle do also have accountability for effective leadership of NHS medical and nursing services and the performance of Public Health England, the accountability for decisions rather than technical advice lies with ministers. The old mantra is: "Advisers advise. Ministers decide."

\section{The public domain}

Of course, critics might lay off these individuals (or perhaps attack them more) if every piece of advice they gave was reported openly and in real time. For instance, minutes from NERVTAG (the New and Emerging Respiratory Virus Threats Advisory Group) are in the public domain, as are (in retrospect) those of the Scientific Advisory Group for Emergencies (SAGE), which has been meeting since January, chaired by Vallance. He stated on 22 April that he didn't want its membership and deliberations openly available in real time because it would lead to members being pressurised, lobbied, or worse-although 
some names entered the public domain, and the composition of the group was then criticised in the Guardian by Anthony Costello for its lack of diversity and relevant expertise. ${ }^{7}$

As for the Cabinet Office's cross agency emergency planning meetings, ${ }^{8}$ it might be hard for the government to transact any business if these meetings (and advice from doctors, nurses, and scientists) were all public. Some may think that it would just lead to the real meeting happening somewhere else, with no minutes. Others may say that, if your strong advice has been deliberately ignored or misrepresented, it would be grounds for going public or resigning-but where does that line lie?

I'm not saying that the performance of medics and scientists has always been flawless or sure footed. I'm saying that their jobs are difficult but much needed, and we should probably give them a break and assume that they're acting in good faith.

What seriously concerns me is ministers repeatedly saying that they're "following the scientific advice." I do hope that they won't seek to dump blame on appointees who are not electorally accountable.
Competing interests: See www.bmj.com/about-bmj/freelance-contributors.

Provenance and peer review: Commissioned; not externally peer reviewed.

1 Stewart H, Busby M. Coronavirus: science chief defends UK plan from criticism. Guardian $2020 \mathrm{Mar} 13$. https://www.theguardian.com/world/2020/mar/13/coronavirus-science-chiefdefends-uk-measures-criticism-herd-immunity.

2 Coronavirus: Jenny Harries criticised for "patronising" remark about "exemplar preparedness". Sky News 2020 Apr 20. https://news.sky.com/story/coronavirus-jennyharris-criticised-for-patronising-remark-about-exemplar-preparedness-11975652.

3 Siddique $\mathrm{H}$. UK clinicians: revised PPE guidance must be backed by adequate supplies. Guardian 2020 Apr 2. https://www.theguardian.com/world/2020/apr/02/clinicians-revisedppe-guidance-inadequate-supplies.

4 Murphy N. "Inappropriate" to say how many NHS staff have died from coronavirus says nursing chief. Mirror 2020 Apr 10. https://www.mirror.co.uk/news/uk-news/breakinginappropriate-say-how-many-21848399.

5 NHS England. An introduction to the NHS. https://www.england.nhs.uk/participation/nhs/

6 Defty A. Do advisers advise while Ministers decide? Who Runs Britain? 2013 Dec 4. https: //whorunsbritain.blogs.lincoln.ac.uk/2013/12/04/do-advisers-advise-while-ministers-decide/

7 Costello A. The government's secret science group has a shocking lack of expertise. Guardian 2020 Apr 27. https://www.theguardian.com/commentisfree/2020/apr/27/gapssage-scientific-body-scientists-medical.

8 Institute for Government. COBR (COBRA). 23 Jan 2020. https://www. instituteforgovernment.org.uk/explainers/cobr-cobra.

Published by the BMJ Publishing Group Limited. For permission to use (where not already granted under a licence) please go to http://group.bmj.com/group/rights-licensing/ permissions 